\title{
Biomassa Kerang Anadara granosa pada Perairan Pantai Kabupaten Indragiri Hilir
}

\author{
Syafruddin Nasution \\ Fakultas Perikanan dan Kelautan, Universitas Riau, \\ Kampus Bina Widya JI. HR Subrantas KM 12,5 Pekanbaru 28293 \\ Diterima 16-03-2009 Disetujui 29-05-2009
}

\begin{abstract}
The present study was carried out to investigate the biomass of cockle (Anadara granosa) from coastal waters of South Indragiri District, Riau Province. The biomass was investigated by quadrad sampling method in the intertidal area along the Concong beach, where fishing of cockles mainly occured. The first station was near by the Concong estuary, while the second station was about 3 miles away from the fisrt one. Samples were collected from three different portions of the intertidal zone that of High Intertidal Mid-Intertidal, and Low Intertidal. The result showed that the highest biomass was found at the lower partion of the intertidal zone. Soft tissue of $A$. granosa was about $\mathbf{2 4 . 8} \%$ of total wet-weight and $\mathbf{7 . 2} \%$ of dry-weight. While material organic was about $85 \%$ of soft tissue dry-weight. Water qualities of the sampling station showed that the overall water qualities were still in normal condition.
\end{abstract}

Keywords: Biomassa, Anadara granosa, Intertidal, South Indragiri

\section{PENDAHULUAN}

Kerang Anadara granosa termasuk ke dalam phylum mollusc, kelas bivalvia, Ordo Arcoida, Familia Arcidae dan merupakan salah satu spesies dari Genus Anadara (Broom, 1985) (Gambar 2). Spesies ini menyebar di kawasan Indo-Pasifik. Dari Afrika sampai Australia, Polynesia dan Jepang. A. garanosa hidup terutama di zona intertidal laut sampai kedalaman air dua meter, menyelam ke dalam pasir atau Lumpur (Pathansali, 1966). Sebagaimana kerang pada umumnya, $A$. granosa memiliki pertumbuhan relative lambat atau sekitar 4,5-31,5 mm pada tahun pertama (Broom, 1982). Kerang darah banyak ditemukan di kawasan pantai Kabupaten Indragiri Hilir karena bentuk pantainya yang landai dan bersubstrat lumpur dengan lebar zona intertidal mencapai lebar 600 meter.

Spesies kerang $A$. Granosa memiliki nilai ekonomis penting serta memiliki kandungan protein yang cukup tinggi yaitu antara $12-14 \%$ dari berat daging yang dikonsumsi (Mubarak, 1987). Disamping itu, komoditas ini merupakan makanan yang sangat digemari di kalangan masyarakat Riau khususnya. Ibrahim (1994), mengatakan bahwa A. granosa merupakan makanan laut yang sangat populer di kalangan masyarakat Asia Tenggara pada umumnya.
Kerang darah merupakan salah satu andalan hasil laut dari Kabupaten Indragiri Hilir, di samping berbagai jenis ikan dan udang yang bernilai ekonomis tinggi. Seiring dengan meningkatnya permintaan akan kerang di pasaran baik dalam memenuhi kebutuhan lokal maupun daerah di luar Kabupaten Indragiri Hilir, menyebabkan ekploitasi sumberdaya ini cenderung mengesampingkan prinsip-prinsip kelestarian sumber daya alam. Di samping itu, semakin meningkatnya aktivitas masyarakat di kawasan ini, dapat pula menambah tekanan terhadap kelestarian sumberdya kerang di pantai tersebut.

Mengingat fenomena tersebut di atas, dikhawatirkan akan berdampak terhadap kelestarian kerang $A$. granosa di daerah tersebut. Untuk itu sangat penting dilakukan penelitian yang seksama untuk mengetahui informasi tentang status biomassa kerang A. granosa dari perairan pantai Indragiri Hilir. Tujuan utama dari penelitian ini adalah untuk mengetahui biomassa kerang Anadara granosa pada zona intertidal pantai laut Kabupaten Indragiri Hilir, Riau. Diharapkan hasil penelitian ini dapat dijadikan sebagai informasi awal bagi usaha pengelolaan sumberdaya hayati laut khususnya kerang $A$. granosa di Kabupaten Indragiri Hilir, Riau.

Telp: +628127552564

Email: Sy_nas@unri.ac.id 


\section{BAHAN DAN METODE}

Lokasi Penelitian. Penelitian ini dilaksanakan di perairan pantai Desa Concong Luar, Kabupaten Indragiri Hilir, Propinsi Riau (Gambar 1). Semua sampel yang diperoleh dianalisis di Laboratorium Kualitas Air Fakultas Perikanan dan Ilmu Kelautan Universitas Riau.

Bahan dan Alat Penelitian. Peralatan yang digunakan untuk pengambilan sample kerang di lapangan meliputi papan selancar (tongkah), petakan kuadrat (frame) ukuran $1 \times 1 \mathrm{~m}$ yang terbuat dari kayu, sekop, saringan $(0,5 \mathrm{~mm})$ untuk memisahkan kerang dengan substrat, dan kantong plastik yang telah diberi label stasiun dan titik sampling, sebagai wadah sampel kerang. Untuk analisis sampel di laboratorium Biologi Laut Fakultas Perikanan Universitas Riau. Peralatan yang digunakan meliputi baki plastik, pinset, timbangan analitik ANB dengan ketelitian 0,01 g untuk menimbang sampel, oven pengering sampel, crucible dan alumunium foil sebagai wadah sampel saat pengeringan dan pembakaran, furnace dan desicator. Kualitas air diukur pada waktu pasang air laut dengan menggunakan peralatan yang meliputi DO meter, termometer air raksa, $\mathrm{pH}$ universal, hand refractometer, dan sechi disk.

Metode Sampling. Sampel kerang A. Garanosa diambil dari dua stasiun penelitian yang sudah ditentukan, masing-masing pada tiga zona intertidal yaitu Intertidal Bahagian Atas (IBA), Intertidal Bagian Tengah (IBT), dan Intertidal Bagian Bawah (IBA). Stasiun 1 merupakan daerah yang berdekatan dengan muara Sungai Concong yang juga dekat dengan pemukiman, pelabuhan pendaratan ikan dan pelabuhan umum. Stasiun 2 merupakan kawasan pesisir yang masih tergolong alami yang banyak ditumbuhi hutan mangrove, sekitar 3 mil dari stasiun 1. Baik stasiun 1 maupun stasiun 2 merupakan centra-centra penangkapan kerang bagi penduduk setempat.

Sampel kerang diambil pada saat titik sampling mulai terekspose pada waktu surut dengan tahapan sbb: petakan kuadrat diletakkan secara acak pada permukaan substrat, lalu sedimen di dalam petakan diambil sampai kedalaman $10 \mathrm{~cm}$ dengan menggunakan sekop. Sedimen disaring dengan menggunakan saringan $1 \mathrm{~mm}$ dan kerang dimasukkan ke dalam kantong plastik yang sudah diberi label stasiun dan titik sampling, lalu diawetkan di dalam

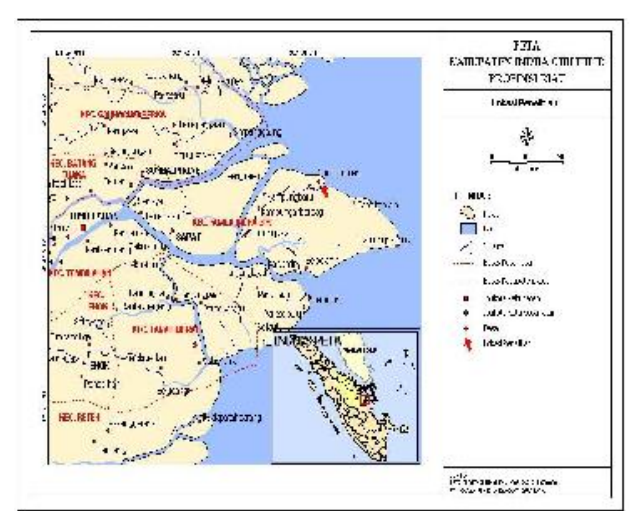

Gambar 1. Peta Kabupaten Indragiri Hulu yang menunjukkan lokasi

kotak berisi es batu dan dibawa ke laboratorium untuk analisis selanjutnya.

Analisis Biomassa Kerang Anadara granosa.

Biomassa kerang $A$. granosa ditentukan dengan menganalisis berat basah, berat kering, dan kandungan organik jaringan lunaknya. Sampel kerang terlebih dahulu dikeringkan dengan menggunakan kertas tissue. Berat basah yang diukur meliputi berat basah total dan berat basah jaringan lunak dengan menggunakan timbangan analitik ketelitian 0,01 gram. Untuk menentukan berat kering dilakukan dengan cara mengeringkan jaringan lunak dari kerang di dalam oven pengering dengan suhu $105^{\circ} \mathrm{C}$ selama 24 jam hingga mencapai berat konstan. Setelah kering dimasukkan ke dalam desikator untuk mendinginkan sampel dan selanjutnya ditimbang. Sampel $A$. granosa yang telah dikeringkan dimasukkan ke dalam crucible dan dibakar di dalam furnace $550^{\circ} \mathrm{C}$ selama 6 jam. Setelah itu dimasukkan ke dalam desikator, lalu ditimbang dengan menggunakan timbangan analitik. Berat material organik dari $A$. granosa adalah nilai berat kering dikurangi nilai berat abu ( Brower et al., 1990).

$$
\text { Berat material organik }=\mathrm{Wd}-\mathrm{Wf}
$$

Di mana :

Wd $=$ berat kering $\left(\mathrm{g} / \mathrm{m}^{2}\right)$

$W f=$ berat $a b u\left(g / m^{2}\right)$

Data yang diperoleh disajikan dalam bentuk tabel lalu dianalisis secara statistik dan diinterprestasikan secara deskriptif. Untuk membandingkan biomassa $A$. granosa antara stasiun digunakan uji-t, sedangkan untuk membandingkan biomassa $A$. granosa pada zona 
intertidal bagian atas, tengah dan bawah digunakan uji F (Sudjana, 1992).

\section{HASIL DAN PEMBAHASAN}

Secara geografis Concong terletak pada posisi $103^{\circ}$ 20' BT - $103^{\circ} 40^{\prime}$ BT dan $0^{\circ} 10^{\prime}$ LS - 0 $0^{\circ} 20^{\prime}$ LS yang termasuk dalam Kecamatan Kuala Indragiri, sekitar $44 \mathrm{~km}$ dari ibu kota Kabupaten Indragiri Hilir (Tembilahan) Riau (Gambar 1). Pantai Concong memiliki tingkat kemiringan rendah atau landai, sehingga wilayah pasang surutnya (intertidal zone) terekpose membentang luas sekitar $1 \mathrm{~km}$ dari batas pasang tinggi ke arah laut pada waktu surut rendah. Seperti juga pada pantai-pantai landai lainnya, pantai ini juga meupakan pantai bersubstrat lumpur halus. Sedangkan kawasan pesisirnya ditumbuhi oleh vegetasi mangrove (Gambar 1).

Hasil pengukuran kualitas air pada zona intertidal pantai Concong Luar yang meliputi parameter fisika yakni suhu, $\mathrm{pH}$, oksigen terlarut, salinitas, dan kecerahan dan dapat dilihat pada Tabel 1. Perbedaan suhu antara stasiun 1 dan stasiun 2 tidak terlalu jauh, hal ini disebabkan terutama oleh adanya pasang surut air laut yang menyebabkan pergerakan massa air yang terus-menerus sehingga suhu perairan tersebar merata di daerah intertidal sewaktu pasang. Broom (1985) yang menyatakan bahwa suhu optimal bagi kehidupan kerang A. granosa adalah sekitar $25-32^{\circ} \mathrm{C}$.

Kisaran $\mathrm{pH}$ air laut optimum bagi yakni 6-9 (KEP02/MENKLH/I/1988). Konsentrasi oksigen dalam penelitian ini masih dikategorikan mendukung kehidupan kerang A.Granosa karena Poernomo \& Hanafi (1982) yang menyatakan bahwa kadar oksigen terlarut minimum 3,0 ppm sudah cukup mendukung kehidupan organisme perairan secara normal asalkan tidak terdapat senyawa beracun di perairan tersebut. Demikian juga salinitas masih dalam kisaran normal untuk suatu perairan estuaria, meskipun salinitas pada stasiun 2 sedikit lebih tinggi dibandingkan dengan salinitas pada stasiun 1. Hal tersebut diduga karena

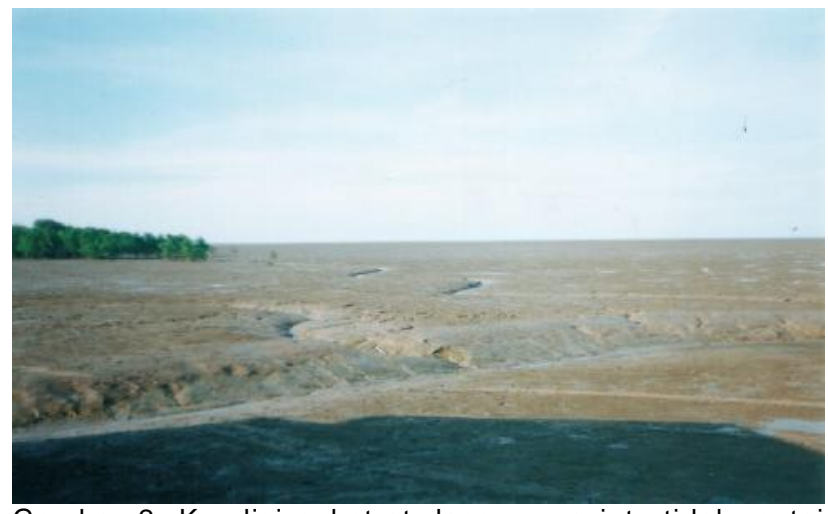

Gambar 2. Kondisi substrat dasar zona intertidal pantai Concong Indragiri yang didominasi lumpur

stasiun 2 lebih banyak dipengaruhi oleh laut dan sedikit sekali pengaruh resapan air tawar yang menyebabkan salinitas menjadi tinggi. Berbeda dengan satasiun 1 yang mendapat input air tawar dari daratan melalui Sungai Concong. Kecerahan perairan pantai lokasi penelitian tergolong rendah karena berdasarkan standar baku mutu air laut menurut KEP-02/MENKLH/I (1988) kecerahan yang baik yakni $>50 \mathrm{~cm}$. Rendahnya kecerahan Perairan Concong disebabkan karena pantainya yang keruh dan tingginya kandungan zat organik tersuspensi pada kolom air.

Biomassa A. granosa. Hasil pengukuran terhadap sampel kerang $A$. granosa mengenai berat basah dimana terdiri dari: berat basah total dan berat basah jaringan lunak (daging) didapatkan perbedaan yang signifikan antara berat basah daging dan berat basah total. Berat basah yang tertinggi ditemukan pada pada stasiun 2 , baik berat basah total maupun berat basah jaringan lunaknya. Namun demikian apabila dibandingkan antara ke dua stasiun, maka tidak terdapat perbedaan yang mencolok. Perbedaan biomassa antara stasiun 1 dan stasiun 2 yang terdapat pada perairan pantai Concong lebih jelasnya dapat dilihat dalam Gambar 2.

Hasil penelitian memperlihatkan perbedaan yang mencolok antara berat basah total dan berat basah daging $A$. granosa. Kisaran berat basah $A$. granosa per satuan luas pada perairan pantai Concong adalah

Tabel 1. Hasil pengukuran parameter kualitas air pada waktu pasang di lokasi penelitian

\begin{tabular}{|c|c|c|c|c|c|c|}
\hline Stasiun & Ulangan & Suhu $\left({ }^{\circ} \mathrm{C}\right)$ & $\mathrm{pH}$ & DO (ppm) & Salinitas (\%०) & Kecerahan (cm) \\
\hline \multirow{3}{*}{ I } & 1 & 30 & 7 & 4,5 & 23 & 37 \\
\hline & 2 & 29 & 8 & 3,8 & 24 & 43 \\
\hline & 3 & 28 & 7 & 4,0 & 26 & 35 \\
\hline Rata-rata & & 29 & 7,3 & 4,1 & 24,3 & 38,3 \\
\hline \multirow{3}{*}{ II } & 1 & 31 & 7 & 4,8 & 29 & 40 \\
\hline & 2 & 31 & 8 & 3,8 & 28 & 45 \\
\hline & 3 & 29 & 6 & 4,3 & 29 & 41 \\
\hline Rata-rata & & 30,3 & 7 & 4,3 & 28,6 & 42 \\
\hline
\end{tabular}


berat basah total yakni $91,14-208,95 \mathrm{~g} / \mathrm{m}^{2}$ dan berat basah daging 22,00-49,10 g/m². Namun uji statistik (uji t) yang dilakukan terhadap kedua stasiun pengamatan memperlihatkan bahwa tidak terdapat perbedaan yang nyata antara biomassa $A$. granosa di stasiun I dibandingkan dengan di stasiun 2.

Perbedaan yang terlihat pada gambar 2 tersebut lebih disebabkan oleh jumlah dan ukuran individu kerang, dimana pada stasiun dua sedikit lebih tinggi dari kerang yang ditemukan pada stasiun 1 . Kecenderungan lebih rendahnya biomassa kerang $A$. granosa pada stasiun 1 dibandingkan dengan pada stasiun 2 berkemungkinan disebabkan oleh faktor intensitas penangkapan. Nelayan yang berasal dari Desa Concong setiap hari menangkap kerang dari pantai yang lebih dekat dengan pemukiman mereka karena mudah dijangkau. Lain halnya dengan stasiun 2 yang relative jauh dari pemukiman, ditambah pula dengan kesulitan untuk menjangkau lokasi ini karena harus melalui hamparan lumpur lunak dan tebal, sehingga tidak banyak dikunjungi oleh masyarakat pencari kerang, sehingga populasinya relative labih terjaga. Selain faktor penangkapan, kemungkinan faktor lain yang menyebabkan stasiun 2 cenderung memiliki nilai biomassa $A$. granosa yang lebih tinggi karena kawasan hutan mangrovenya yang masih tergolong subur. Sugiarto, (1995), berpendapat bahwa hutan mangrove berfungsi sebagai tempat pelestarian ikan, udang, kepiting dan kerang-kerangan karena mangrove merupakan sumber nutrisi bagi perairan sehingga banyak tersedianya serasah, jenis alga dan plankton yang menjadi sumber makanan bagi biota pantai.

Namun dibandingkan antara masing-masing zona intertidal (uji F), maka diketahui ternyata ada perbedaan yang nyata antara IBA (Intertidal Bagian Atas), IBT (Intertidal Bagian Tengah) dan IBB (Intertidal Bagian

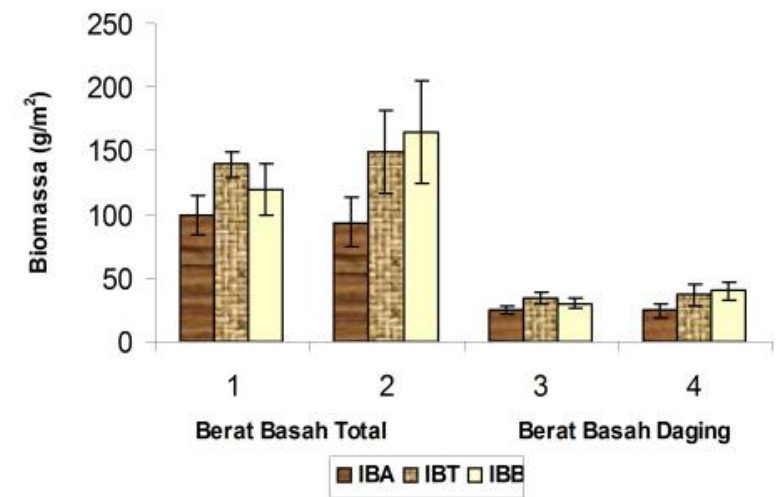

Gambar 3. Rata-rata berat basah A. granosa pada masing-masing stasiun pengamatan $( \pm S D)$
Bawah). Biomassa kerang $A$. granosa yang tertinggi ditemukan pada zona IBB (Intertidal Bagian Bawah) yang lokasinya lebih dekat dengan laut dengan nilai rata-rata berat basah total $142,05 \mathrm{~g} / \mathrm{m}^{2}$ dan rata-rata berat basah daging $34,76 \mathrm{~g} / \mathrm{m}^{2}$. Tingginya biomassa A. granosa pasa daerah intertidal bawah diduga karena daerah ini selalu terendam air pada waktu surut dibandingkan dengan porsi intertidal lainnya sehingga kerang terhindar dari kekeringan dan kenaikan suhu yang ekstrim. Di samping itu kondisi yang demikian itu menyebabkan tempat penumpukan nutrisi berupa bahan organik yang dibutuhkan oleh kerang baik yang berasal dari darat maupun dari laut. Einsele, (1992), menyatakan bahwa sebahagian besar bahan organik laut berasal dari daratan masuk ke laut melaui proses mineralisai dan mengendap di dasar pantai, Bahan organik biasanya lebih banyak terdapat di perairan dangkal dan muara sungai dibandingkan dengan laut dalam karena kandungan karbon akan berkurang secara vertikal akibat menurunnya produksi primer oleh proses mineralisasi di kolam air sebagai akibat dari aktivitas organisme dasar laut. Namun demikian, dikatakan pula bahwa dengan adanya pergerakan massa gravitasi maka dapat mengangkat sedimen yang kaya akan bahan organik dari dasar perairan pantai dan muara.

Pada zona IBB ditemukan iondividu-individu yang sebahagian besar mempunyai ukuran yang relative besar bila dibandingkan dengan ukuran individu di zona tengah dan atas, sehingga biomassa $A$. granosa cenderung lebih besar pada zona IBB (Intertidal Bagian Bawah) ini. Odum (1993) menyatakan bahwa semakin besar ukuran dari suatu organisme maka biomassanya juga akan semakin tinggi.

Berat Kering A. granosa. Kisaran berat kering A. granosa dari perairan pantai Concong yakni berat

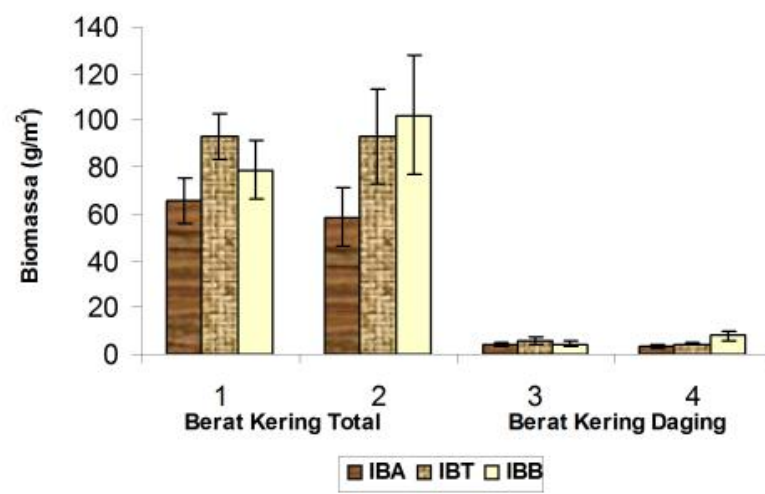

Gambar 4. Rata-rata berat kering A. granosa pada masing masing stasiun dan zona Intertida $( \pm S D)$ 


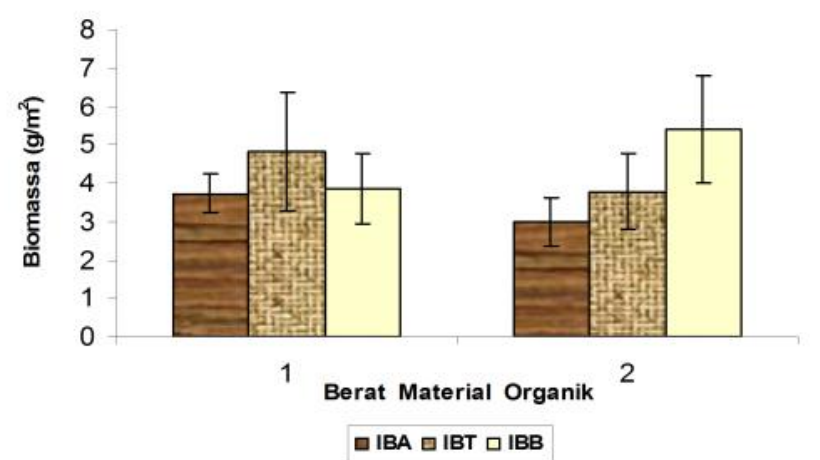

Keterangan: IBA $=$ Intertidal Bagian Atas, IBT $=$ Intertidal Bagian Tengah, IBB = Intertidal Bagian Bawah

Gambar 4. Nilai rata-rata berat material organik $A$. granosa pada kedua stasiun penelitian, $\pm \mathrm{SD}(\mathrm{n}=5)$

kering total $40,97-135,43 \mathrm{~g} / \mathrm{m}^{2}$ dan berat kering daging berkisar dari 2,51-9,83 $\mathrm{g} / \mathrm{m}^{2}$. Setelah sampel dikeringkan, terdapat perbedaan nyata antara berat kering total dan berat kering jaringan lunak (daging) kerang darah Anadara granosa (Gambar 4).

Ketika dibandingkan biomassa antara tiga zona intertidal di kedua stasiun pengamatan, maka terdapat kecenderungan bahwa biomassa kerang $A$. Granosa pada zona bawah yang letaknya sebelah laut selalu lebih tinggi dibandingkan dengan zona tengah, dan zona intertidal atas. Ini menunjukkan bahwa faktor kekeringan atau lama terekpose wilayah ini kelihatannya sangat berpengaruh terhadap distribusi kerang di wilayah intertidal.

Biomassa kerang A. Granosa dapat pula dicermati dari sudut kandungan bahan organik pada jaringan lunaknya. Hasil pengabuan jaringan lunak memperlihatkan variasi baik antar satsiun maupun antar zona intertidal. Berat material organik $A$. granosa lebih jelasnya dapat dilihat pada Gambar 5 .

Dari Gambar 5 dapat dilihat hasil penelitian memperlihatkan bahwa rata-rata berat material organik A. granosa dari perairan pantai Concong cenderung lebih tinggi ditemukan pada stasiun 2 yakni $4,06 \mathrm{~g} / \mathrm{m}^{2}$, sedangkan rata-rata berat material organik yang cenderung lebih rendah ditemukan pada stasiun 1 (4,03 $\mathrm{g} / \mathrm{m}^{2}$ ) (Gambar 4). Setelah diuji secara statistik ternyata tidak terdapat perbedaan yang nyata antara kedua stasiunpenangkapan yang dilakukan oleh nelayan Concong telah memberikan pengaruh terhadap nilai biomassa $A$. granosa yang didapat. Biomassa dari kandungan material organik suatu organisme merupakan sumber pemasukan energi bagi lingkungan habitatnya dalam meningkatkan kesuburan perairan.

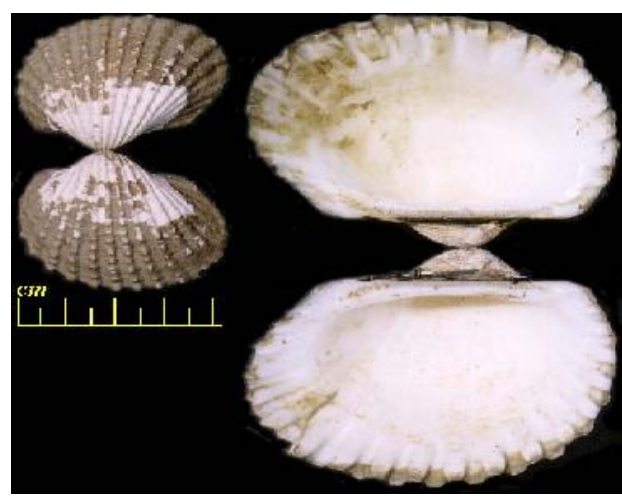

Gambar 5. Kerang darah, Anadara granosa dari pantai Concong Luar, Kabiupaten Indragiri Hilir.

\section{KESIMPULAN DAN SARAN}

Dari hasil penelitian diketahu bahwa secara lokal antara stasiun 1 dan 2 terdapat variasi biomassa kerang Anadara granosa pada perairan Pantai Concong khususnya dan perairan Intertidal pada umumnya. Pada daerah yang lebih jauh dari jangkauan penduduk yaitu stasiun 2, terdapat biomassa kerang yang lebih tinggi dibandingkan biomassa kerang pada stasiun 1 yang lebih banyak dikunjungi oleh masyarakat. Di samping itu daerah intertidal bahagian bawah memiliki biomassa kerang yang lebih tinggi dibandingkan dengan intertidal bahagian tengah dan intertidal bahagian atas.

Disarankan bagi penelitian selanjutnya dapat menganalisis biomassa dari sudut pandang yang lain seperti kandungan energi yang terdapat pada kerang darah Anadara granosa pada satuan luas tertentu dari daerah intertidal di pantai yang sama.

\section{UCAPAN TERIMA KASIH}

Penulis menyampaikan ucapan terima kasih kepada Universitas Riau melalui Lembaga Penelitian Universitas Riau yang telah mendanai dan mengkoordinasikan pelaksanaan penelitian ini mulai dari proposal sampai kepada penyelesaian laporan penelitian.

\section{DAFTAR PUSTAKA}

Broom, M.J. 1982. Analysis of growth of Anadara granosa (L.) (Bivalvia:Arcidae) in natural, artifially seeded and experimental populations. Mar. Ecol. Progr. Ser. 9: 69-79.

Broom, M.J. 1985. The Biology and Culture of Marine Bivalva Mollusc of the Genus Anadara. International Centre for Living Aquatic Resources Management. Manila. 37.

Brower. J.E, Jerrold H.Z., \& Von Ende, C.N. 1990. Field and Laboratory Methods for General Ecology. $3^{\text {rd }}$ ed.

Debora, Y. 2002. Biomassa Kerang Darah Anadara granosa Dari Perairan Panipahan Kabupaten Rokan Hilir Propinsi Riau. Skripsi. Fakultas Perikanan dan IImu Kelautan. Universitas Riau. 52. 
Einsele, G. 1992. Sedimentary Basins (Evolution, Facies and Sediment Budget). Springer Verlaag, Berlin Heidenberg, 628.

Ibrahim, N. 1994. Determination of trace elements in cockle Anadara granosa (L) using INAA. Aplied radiation and isotopes, Vol. 45: 897-898.

Keputusan Menteri KLH No. 02. 1988. Pedoman Penetapan Baku Mutu Lingkungan. Sekretariat Menteri KLH. Jakarta. 51.

Mubarak, H. 1987. Penentuan Lokasi Budidaya Kerang Darah di Perairan Blanakan Jawa Barat. Jurnal Penelitian Perikanan Laut Jakarta 42-49.

Odum, E.P. 1993. Dasar-Dasar Ekologi Edisi Ketiga. Terjemahan T. Samingan. Gadjah Mada University Press. Yogyakarta. 630.
Pathansali, D. 1966. Notes on the biology of the cockle, Anadara granosa L. Proc. Indo-Pacific Fish. Counc. 11: 84-98

Ridwan, B.H., Zahala, B.G., Norgadi, B.I., \& Johnson, N.A. 1986. Species Bivalva, Sumber laut di Sabah. Sumber. 2: 141-150.

Safitri. E. 2003. Struktur Komunitas Gastropoda (mollusc) di Hutan Mangove Muara Sungai Donan Kawasan BKPH Rawa Timur, KPH. Banyumas Cilacap, Jawa Tengah. Fakultas Perikanan IPB. Bogor. 63.

Sudjana, M.A. 1992. Metoda Statistik. Bandung: Tarsito. Halaman 508.

Sugiarto, M.S. \& Ekariyono, W. 1995. Penghijauan Pantai. Jakarta: Penebar Swadaya. Halaman 79. 